\author{
Душка Б. КЛИКОВАЦ \\ Филолошки факултет \\ Универзитета у Београду
}

\title{
О ЗНАКОВИМА У ПРАВОПИСУ (3): НЕРЕЧЕНИЧНИ (ПОМОЋНИ) ПРАВОПИСНИ ЗНАЦИ И НЕКОЛИКО НАПОМЕНА О ПРАВОПИСНИМ ЗНАЦИМА УОПШТЕ
}

\begin{abstract}
У раду се најпре бавимо помоћним правописним знацима: коментаришемо једну употребу термина помоћни правописни знаци која се појавила у литератури, наводимо дефиниције помоћних правописних знакова дате у правописима, разматрамо инвентар интерпункцијских знакова који се могу употребити и као помоћни правописни, наводимо помоћне правописне знаке који се налазе у досадашњим правописима и коментаришемо критеријуме по којима се ти знаци укључују у правописе. Затим пажњу посвећујемо различитим аспектима правописних знакова уопште: њиховом именовању, начинима на које се читају наглас, односима међу њима и дефинисању свих правописних знакова заједно.
\end{abstract}

Кључне речи: српски језик, правопис, правописни знаци, помоћни правописни знаци, нереченични правописни знаци, правописна синонимија, правописна полисемија, правописна хомонимија

\section{1. Увод}

Први део овог рада (Кликовац 2017) био је посвећен подели правописних знакова (=свих знакова који се користе у правопису) на реченичне и нереченичне и терминима који се за њих користе; предложили смо термине интерпункиијски или реченични знакови (оба су традиционални термини управо с тим значењем), односно помоћни или нереченични (први термин су увели Пешикан и др. 1993, а преузели и Пижурица и др. 2010).

У 2. делу рада (Кликовац 2018a) бавили смо се реченичним знаковима - њиховом дефиницијом и њиховим инвентаром. Указали смо и на њихове одлике по којима се разликују од нереченичних знакова и због којих би, по нашем мишљењу, требали да имају посебно место у правопису: 1) они, бар начелно, одговарају елементима прозодије; 2) без њих се не може написати ни најједноставнија реченица; 3) њихово усвајање у вези је са усвајањем од- 
ређених синтаксичких знања; 4) њима је могуће стилски нијансирати исказ. Поменули смо и да би се могла увести терминолошка разлика између правописних знакова у ужем смислу - а то су они који се дописују словима, речима, реченицама или читавом тексту, и правописних знакова у ширем смислу - а то су они који се на другачије начине комбинују са словима: велико слово на почетку реченице, тип слова, белине. (Указали смо и на другачије решење - да се само они први знакови сматрају правописним, а да се ови други, уз рашчлањавање на пасусе, разбрајање на делове и фусноте, сматрају нечим чиме се правописни знаци „допуњавају” - како кажу Пешикан и др. 1993.)

У овом делу рада бавимо се најпре помоћним правописним знацима: коментаришемо једну употребу термина помоћни правописни знаци која се појавила у литератури (т. 2), наводимо дефиниције нереченичних знакова дате у правописима (т. 3), разматрамо инвентар интерпункцијских знакова који се могу употребити и као помоћни правописни (т. 4), наводимо помоћне правописне знакове који се налазе у досадашњим правописима, коментаришући критеријуме по којима се ти знакови укључују у правописе (т. 5).

Затим пажњу посвећујемо различитим аспектима правописних знакова уопште: њиховом именовању (т. 6), начинима на које се читају наглас (т. 7), односима међу њима (т. 8) и дефинисањем свих правописних знакова заједно (т. 9). Рад завршавамо Закључком (т. 10).

\section{2. Једно терминолошко питање}

Видели смо (Кликовац 2017) да термин који би означио групу знакова који се не тичу реченице уводи тек Боранић ${ }^{10} 1951$ [1921]. То је термин правописни знащи. Њега преузимају Правопис 1960, Симић и др. 1998 (и Симић 2003), Бабић и др. ${ }^{6} 2002$ [1996], као и Шипка (2000). Анић и Силић 2001 употребљавају термин правописни знакови у ширем смислу (за разлику од оних у ужем смислу - реченичних).

Пешикан и др. (1993), већ у уводном делу поглавља о правописним знацима (стр. 253), за нереченичне знакове уводе термин помоћни правописни знакови:

У интерпункцији [=свим правописним знацима] се могу разликовати реченични знакови - који указују на границе пуних реченица и суреченица, на њихов карактер, као и на односе и одлике њихових делова - и помоћни правописни знакови, за различите посебне потребе.

Затим, мало даље на истој страни, кажу:

Најважнију улогу [међу свим правописним знаковима] имају они знакови који су неопходни за уобличавање писане реченице. То су пре свега тачка, као знак који заједно с великим словом показује границе пуних реченица, и запета или зарез, знак најбитнији за предочавање унутрашњих односа у реченици [...]. - Без зареза и тачке није могућно исправно писање ни најједноставнијих текстова, а многе реченице својим карактером и склопом изискују и друге реченичне знакове: црту, тачку са зарезом, наводнике, двотачку (или две тачке), заграду, упитник и (знатно ређе) узвичник. 
Дакле, изричито се набрајају реченични знаци, ${ }^{1}$ као што је јасно истакнута и њихова улога („најважнија”) међу свим знаковима, јер су „неопходни за уобличавање писане реченице".

Преправљено издање овог правописа (Пижурица и др. 2010: 143), међутим, уноси извесну пометњу:

Интерпункцијски [=правописни] знаци су: тачка [.], запета [,], ирта [-], тачка са запетом//тачка запета [;], наводниции [," "], упитник [?], узвичник [!], иртициа [-] и остали правописни и помоћни знакови.

Наиме, није јасно по ком критеријуму су наведени баш ти знаци. Од реченичних знакова недостају бар двотачка и заграда (ако већ не и тротачка), а у списку се нашла иртица, која је нереченични знак. Биће да двотачка и заграда недостају грешком, јер о тим знацима аутори у наставку посебно говоре - и као о „интерпункцијским” и као о „правописним” [=помоћним правописним]. ${ }^{2}$ А цртицу вероватно ту помињу зато што и о њој говоре под посебним поднасловом (као што то чине и аутори правописа из 1993). Дакле, Пижурица и др. одступају од претходне верзије Правописа српскога језика утолико што, пре него што ће се посветити правописним знацима појединачно, не набрајају реченичне знаке, него неке правописне знаке.

Термин помоћни интерпункцијски термини користи и В. Брборић, али не дефинише његово значење, осим што га употребљава као комплементаран термину (дакле, и појму) основни интерпункиијски термини, који другде нисмо срели. Није јасно шта би овај други термин означавао, али би се из контекста као што је следећи (Брборић 2018: 68) могло закључити да се мисли на правописне знакове који су најчешћи:

Матичин Правопис из 1993. доноси ове термине, као основне: тачка, запета или зарез, ирта, тачка и запета или тачка и зарез (тачка са зарезом), две тачке (двотачка), заграда, наводници, упитник, узвичник, иртица.

Ово су заиста знаци које Пешикан и др. (1993) обрађују појединачно, посвећујући свакоме посебан одељак означен одговарајућим поднасловом, док остале знакове обрађују у оквиру једног одељка под јединственим насловом „Остали правописни и помоћни знакови”. Аутори су се за то одлучили вођени првенствено припадношћу тих знакова реченичним знаковима - чију важност, видели смо, изричито наглашавају. А зашто посебно обрађују цртицу? Можда зато што о њој имају да кажу више него о другим помоћним знаковима (посвећују јој читаву страницу), а можда и зато да би истакли њену дистинктивност према црти; на ово друго упућује прва реченица унутар одељка посвећеног том знаку (стр. 290):

Док црта начелно служи у организовању и обликовању реченице, цртица у својој основној служби припада лексици, животу речи [...].

\footnotetext{
${ }^{1}$ Недостаје тротачка, коју очигледно не сматрају реченичним знаком - што није оправдано, али у чему нису усамљени (в. т. 4.2. у овом раду).

${ }^{2}$ Ту претпоставку поткрепљују и други пропусти на које се наилази у том правопису (в. Кликовац 2011a, 2011б).
} 
Међутим, знакове које обрађују у појединачним одељцима и с одговарајућим поднасловима Пешикан и др. (1993) нигде не издвајају у посебну групу нити их називају посебним термином. То не чине ни Пижурица и др. (2010). Другим речима, ни у једном ни у другом правопису нема помена о „основним” правописним знаковима, односно о томе да је термин (и појам) помоћни правописни знаци комплементаран било чему другом осим термину (и појму) реченичних знакова. Тог помена има још мање у правописима у којима се не употребљава ни термин помоћни правописни знащи; упркос томе, В. Брборић (2018: 71) тврди:

Постоји [од Вука до данас] јасна подела на основне и помоћне интерпункцијске знаке, број основних је ограничен, док је број помоћних неограничен, а повремено 'стижу' нови знаци и нови термини.

Увођењем појма „основних термина” пометња коју уноси правопис Пижурице и др. (2010) претвара се у појмовну збрку. Наиме, питање учесталости одн. важности знакова релативно је питање и не тиче се суштинске разлике међу знаковима, а подела на реченичне и нереченичне знакове је начелне природе и заснована на природи знакова. ${ }^{3}$

\section{3. Дефиниције нереченичних знакова}

У правописима нема много покушаја да се дефинишу нереченични знакови.

Неки правописи их дефинишу као знакове који се везују за речи. Тако Броз (1892), како смо видели (Кликовац 2017), разликује знакове који се „употребљавају у писању ријечи” и оне који се „биљеже у писању реченица” (он је, узгред, и једини правописац који наводи прво нереченичне, а тек онда реченичне знакове). Слично томе, и Правопис 1960 за те (у изворној терминологији правописне) знаке каже да се употребљавају „уз поједине речи”. Симић и др. (1998) кажу, неодређеније, да ти знаци „обележавају језичке јединице" (стр. 120).

Бабић и др. ('2002 [1996]: 125) дају следеће објашњење: „Pravopisni znakovi služe zato da se odredi kako što treba čitati ili razumjeti. Tako npr. točka iza brojke označuje samo to da brojku treba pročitati kao redni, a ne kao glavni broj." Проблем је, међутим, што помоћу дефиниције дате у првој реченици не бисмо могли разликовати нереченичне знакове од реченичних; да није додат пример, не би се тачно знало о којим знаковима је реч.

Заустављамо се, тако на формулацији коју дају Пешикан и др. (1993: $253)$ - да „помоћни правописни знакови” служе „за различите посебне по-

\footnotetext{
${ }^{3}$ Приметићемо и да сами аутори правописа из 1993. узвичник сматрају знаком који се у реченицама употребљава „знатно ређе” (в. други по реду цитат у овој тачки), што им не смета да га ставе у групу знакова који међу свим правописним знацима имају „најважнију улогу”, управо по његовом својству да служи „уобличавању писане реченице”.
} 
требе”. Наиме, ти знаци су толико разнородни да се може дати само врло уопштена квалификација, и пре свега негативна - да нису интерпункцијски.

\section{4. Који се интерпункцијски знаци могу употребити као помоћни правописни}

4.1. Како смо видели (Кликовац 2017), у неким правописима прави се разлика између реченичних и нереченичних знакова. Ево знакова који се у тим правописима наводе и као реченични и као нереченични, одн. оних чије се обе те употребе разматрају:

\begin{tabular}{|c|c|}
\hline Знак & $\begin{array}{c}\text { Термин којим се тај знак назива и правопис у којем се помиње као } \\
\text { нереченични знак или чија се нереченична употреба објашњава }\end{array}$ \\
\hline . & $\begin{array}{l}\text { тачка (Правопис 1960, Симић и др. 1998), } \\
\text { точка (Броз 1892, Боранић 1951, Бабић и др. }{ }^{6} 2002 \text { [1996], Анић и } \\
\text { Силић 2001) }\end{array}$ \\
\hline , & зарез (Бабић и др. ${ }^{6} 2002$ [1996], Анић и Силић 2001) \\
\hline$:$ & $\begin{array}{l}\text { две тачке (Белић 1950, Правопис 1960), двије точке (Боранић 1951), } \\
\text { двотачка (Симић и др. 1998), двоточка (Анић и Силић 2001), } \\
\text { двоточје (Бабић и др. }{ }^{6} 2002 \text { [1996]) }\end{array}$ \\
\hline ; & точка-зарез (Анић и Силић 2001) \\
\hline- & $\begin{array}{l}\text { uрта (Правопис 1960, Симић и др. 1998, Анић и Силић 2001), } \\
\text { станка (Боранић 1951), } \\
\text { цртица (Бабић и др. }{ }^{6} 2002 \text { [1996]) }\end{array}$ \\
\hline-- & црте (Анић и Силић 2001) \\
\hline$=$ & двострука цртица (Анић и Силић 2001) \\
\hline$, ", " \gg \ll$ & наводнищи (Бабић и др. ${ }^{6} 2002$ [1996], Симић и др. 1998) \\
\hline , & полунаводници (Бабић и др. ${ }^{6} 2002$ [1996]) \\
\hline$?$ & упитник (Бабић и др. ${ }^{6} 2002$ [1996], Анић и Силић 2001) \\
\hline$!$ & ускличник (Бабић и др. ${ }^{6} 2002$ [1996], Анић и Силић 2001) \\
\hline$\cdots$ & $\begin{array}{l}\text { три точке (Боранић 1951) } \\
\text { неколико тачака (Правопис 1960) }\end{array}$ \\
\hline ( ) $[$ ] & $\begin{array}{l}\text { обла и угласта заграда (Белић 1950) } \\
\text { заграда (Броз 1892, Боранић 1951, Правопис 1960, Симић и др. 1998), } \\
\text { заграде (Анић и Силић 2001, Бабић и др. }{ }^{6} 2002 \text { [1996]) }\end{array}$ \\
\hline
\end{tabular}

${ }^{4}$ Белић (1950) уопште не говори о реченичним употребама овог правописног знака. 
4.2. У овом списку наводе се неки интерпункцијски знаци који сасвим сигурно имају и нереченичне употребе. То су следећи (уз сваки ћемо навести његове најтипичније употребе као помоћног правописног знака):

- $\quad$ тачка, која се употребљава иза неких скраћеница, иза редних бројева (с одређеним ограничењима), у вишецифреним бројевима да, почев од краја броја, одвоји по три цифре итд.;

- $\quad$ зарез, који се употребљава у децималним бројевима;

- д двотачка, која има и значење „према”;

- црта, која има и значење „од... до...”, а служи и да уведе ставке у набрајању (као што је случај са ставкама које читалац управо сад има пред очима);

- $\quad$ заграда, у коју се ставља факултативан део речи (нпр. акцен(a)m), и други део заграде, који се може употребити да означи редни број (уместо тачке и др. знакова) приликом навођења одељака.

Што се тротачке тиче, тај знак као интерпункцијски има две врсте употреба: (1) да стоји на крају реченице уместо изостављеног текста - било да је тај текст стварно изостављен или се само наговештава могућност да се он на том месту продужи, и (2) да означи дужу паузу унутар реченице, између двеју реченица или чак између два дела текста (опширно овај знак разматра Кликовац 2012). И у једном и у другом случају има прозодијски корелат. Само се у једном случају може сматрати помоћним правописним знаком: кад, обично у загради (угластој или облој), аутор њоме означава да је на том месту изоставио део текста. Тада се у гласном читању на том месту не прави пауза нити има неког другог прозодијског сигнала који би се бележио тротачком.

4.3. Да упитник и узвичник могу бити употребљени и као нереченични знаци, кажу Бабић и др. ('2002 [1996]) и Анић и Силић (2001), али само Бабић и др. ('2002 [1996]: 92) објашњавају која је употреба узвичника таква:

Kao pravopisni znak uskličnik se upotrebljava u zagradama, sam ili s riječima sic!, tako!, kad se želi istaknuti da je što vjerno prepisano, pogotovu ako se prenosi tiskarska pogrješka ili kad se želi upozoriti čitatelja da na to obratu posebnu pozornost.

Реч је, очигледно, о таквој употреби упитника и узвичника за коју Пешикан и др. (1993: 290) кажу:

Упитник, узвичник или оба знака заједно пишу се у загради (облој или угластој) као знак ауторовог става према неком податку или тврдњи која се у тексту наводи. Упитник се овако употребљава кад аутор неки део текста који наводи сматра нејасним или кад се колеба у погледу интерпретације, а узвичником се често наглашава да је текст тачно наведен, тј. да није у питању омашка, иако навод може изгледати необично:

У запису је поменут и оков корица јеванђеља: „Бог да прости ковача Тому јере ми скова мајсторију[?] и приложи”. - Писар се, како је уобичајено, извињава за могуће грешке: „Не писа Дух свети и ангел, но рука грешна и древна[!] и очи дремњивљи”.

Изван оваквих случајева заграђени упитник, узвичник или оба знака обично указују на ауторов негативан став (сумњу, неслагање, иронију и сл.) према ономе што се наводи. У овој служби каткад се пише и удвојени упитник или узвичник. 
Поставља се питање - зашто би се ове употребе упитника и узвичника сматрале нереченичнима? Приметићемо да ти знаци у наведеним случајевима стоје, заправо, уместо читаве реченице: упитник уместо реченице „Да ли је ово сасвим тако?”, а узвичник уместо реченица „Пише баш тако!” или „Тако аутор каже, али ја сматрам да је то крајње неприхватљиво!”. Тако упитник и узвичник стоје, метонимијски, за читаву реченицу на чијем би се крају налазили - што је употреба која се јасно надовезује на реченичну, те се не би могла сматрати помоћноправописном.

4.4. Могућност да се наводници и полунаводници употребе и као нереченични знаци помињу Бабић и др. ('2002 [1996]: 87), али не објашњавају која би то њихова употреба била. Те употребе прецизирају Симић и др. (1998: 119); прва је:

Речи и изрази у недословном и посебном значењу: - Измучен најллупљим егзерциром откако сам у „школи”..., ја вечерас опет размишљам о том очевом „,народу” и твојој „, Србији”...

Друга је „за обележавање наслова, натписа и ознака - ређе при исписивању, а чешће при навођењу".

Овде се поставља исто принципијелно питање као и у случају упитника и узвичника: да ли је довољно да се неки интерпункцијски знак веже за једну реч да би се сматрао нереченичним? Јасно је да су у управо наведеним примерима речи „народ” и „Србија” употребљене као цитат; стога наводници у њима имају исту ону употребу као и кад означавају управни говор - а ово друго је несумњиво реченична употреба. Исту цитатност можемо запазити и онда кад служе да означе „наслове, натписе и ознаке” - што, заправо, примећују и сами аутори кад кажу „ређе при исписивању, а чешће при навођењу” (курзив наш - Д. К.).

Чак и онда кад наводници служе као „пишчева ограда” - тј. „у значењу 'тобожњи', 'лажни' или 'наводни', 'такозвани'” (како кажу Пешикан и др. 1993: 286), њихова употреба је суштински цитатна - било да аутор стварно цитира нечију туђу реч (с којом се не слаже) или се понаша као да ју је неко други изговорио или би је могао изговорити (па се опет с њом не слаже).

Према томе, и кад се под наводницима налази само једна реч, они су употребљени са истим значењем као кад су употребљени као реченични знаци. Због тога бисмо рекли да ни у том случају нису употребљени као помоћни правописни знаци. ${ }^{5}$

\footnotetext{
${ }^{5}$ Овде би се могло отворити питање да ли је заграда помоћни правописни знак кад се употреби у оквиру једне речи, у случајевима као што је акцен $(a) m$ - будући да и тада, као и на нивоу реченице одн. текста, означава део који се може изоставити а да остатак може опстати као целина. Међутим, чини се да је то ипак другачији случај: кад се налази унутар речи, заграда више нема битно својство које има као интерпункцијски знак и на основу којег је дистинктивна према другим интерпункцијским знацима (пре свега удвојеној црти и удвојеном зарезу) - а то је да је део текста који ограђује мање важан, маргиналнији за целокупни текст. Изостанак тог битног својства сврстао би је у категорију помоћних правописних знакова.
} 
4.5. Најзад, Анић и Силић (2001: 7) помињу и да се тачка и зарез („точказарез”) и „црте” (=удвојена црта) могу употребити и као нереченични знаци. Међутим, у одељцима о тим знаковима такве употребе не помињу, нити се види које би оне могле бити. „Двострука цртица” је пак знак који може бити употребљен само као помоћни правописни (в. Кликовац 2018a). Сви ти знаци се као „правописни у ширем смислу” (=помоћни правописни) очигледно помињу грешком.

4.6. Ако један интерпункцијски знак не престаје нужно да буде интерпункцијски простом чињеницом што је употребљен само уз једну реч, поставља се питање питање да ли интерпункцијски знаци који су делатни и на нивоу текста, тј. који могу раздвајати текстуалне целине - а то су црта, тротачка, заграда и наводници - у тој употреби престају да буду интерпункцијски самом том чињеницом што се не везују за реченицу. Сматрамо да је и ту пресудно њихово значење: пошто и у текстуалној употреби имају исто оно значење које имају и на нивоу реченице, и даље их треба сматрати интерпункцијским, а не помоћним правописним. Интерпункцијски знаци се, значи, типично, али не и искључиво, везују за реченицу.

\section{5. Знаци који могу бити само нереченични}

5.1. Осим поменутих знакова, у правописима се појављују и следећи - било да се помињу као нереченични или се наводе у правописима који не праве разлику између реченичних и нереченичних знакова:

\begin{tabular}{|c|c|}
\hline Знак & Правопис у којем се помиње и термин којим се назива \\
\hline - & $\begin{array}{l}\text { везица (Броз 1892, Новаковић 1894), } \\
\text { цртица (Боранић 1951, Правопис 1960, Пешикан и др. 1993, } \\
\text { Дешић 1994, Симић и др. 1998, Шипка 2000, Пижурица и } \\
\text { др. 2010, Дешић 2015, Анић и Силић 2001), } \\
\text { везица (иртииа) (Белић 1923), } \\
\text { везица (полуцрта, иртица) (Белић 1934, Белић 1950), } \\
\text { спојница (Бабић и др. }{ }^{2} 2002 \text { [1996], Хрватски правопис } \\
\text { 2013) }\end{array}$ \\
\hline , & $\begin{array}{l}\text { апостроф (Броз 1892, Новаковић 1894, Белић 1923, Белић } \\
\text { 1934, Белић 1950, Боранић 1951, Правопис 1960, Пешикан } \\
\text { и др. 1993, Дешић 1994, Симић и др. 1998, Шипка } 2000 \text {, } \\
\text { Пижурица и др. 2010, Дешић 2015, Правописно упутство } \\
\text { 1929, Анић и Силић 2001), } \\
\text { изоставник (Бабић и др. }{ }^{6} 2002 \text { [1996], Анић и Силић 2001, } \\
\text { Хрватски правопис 2013) }\end{array}$ \\
\hline
\end{tabular}




\begin{tabular}{|c|c|}
\hline . & $\begin{array}{l}\text { генитивни знак (Боранић 1951, Правопис 1960, Дешић 1994, } \\
\text { Бабић и др. } 2002 \text { [1996], Симић и др. 1998, Дешић 2015), } \\
\text { без термина (Правописно упутство 1929, Белић 1923, Бе- } \\
\text { лић 1934, Белић 1950), } \\
\text { знак дужине (угласти) (Пешикан и др. 1993), } \\
\text { знак дужине (Шипка 2000, Пижурица и др. 2010) }\end{array}$ \\
\hline " & $\begin{array}{l}\text { акценти (Новаковић 1894, Боранић 1951, Пешикан и др. } \\
\text { 1993, Дешић 1994), акценатске ознаке (Симић и др. 1998), } \\
\text { акценатски знаци (Белић 1923, Белић 1934, Белић 1950, } \\
\text { Правопис 1960, Пижурица и др. 2010, Дешић 2015), } \\
\text { „знакови за акценте” (Броз 1892), } \\
\text { знакови за нагласке (Анић и Силић 2001, Хрватски право- } \\
\text { пис 2013), } \\
\text { нагласии (Бабић и др. }{ }^{6} 2002 \text { [1996]) }\end{array}$ \\
\hline$\checkmark$ & знак краткоће (Пешикан и др. 1993, Пижурица и др. 2010) \\
\hline- & $\begin{array}{l}\text { хоризонтална црта (Правописно упутство 1929), } \\
\text { знак за дуљину (Анић и Силић 2001), } \\
\text { знак дуљине (Бабић и др. '2002 [1996]), } \\
\text { ненаглашена дужина (Пешикан и др. 1993), } \\
\text { неакиентована дужина (Дешић 1994, Дешић 2015) } \\
\text { знак за занагласну дужсин (Хрватски правопис 2013) }\end{array}$ \\
\hline$<,>$ & $\begin{array}{l}\text { знаци порекла (Правопис 1960, Пижурица и др. 2010, Де- } \\
\text { шић 2015), } \\
\text { знаци поријекла (Боранић 1951, Шипка 2000), } \\
\text { знакови подријетла (Бабић и др. }{ }^{6} 2002 \text { [1996]), } \\
\text { без термина (Белић 1950) }\end{array}$ \\
\hline l & $\begin{array}{l}\text { коса ирта (Пешикан и др. 1993, Дешић 1994, Симић и др. } \\
\text { 1998, Шипка 2000, Анић и Силић 2001, Пижурица и др. } \\
\text { 2010, Дешић 2015, Хрватски правопис 2013), } \\
\text { коса иртица (Бабић и др. }{ }^{6} 2002 \text { [1996]) }\end{array}$ \\
\hline * & $\begin{array}{l}\text { звездий (Белић 1950, Правопис 1960, Пешикан и др. 1993, } \\
\text { Симић и др. 1998, Пижурица и др. 2010, Дешић 2015), } \\
\text { звјездица (Боранић 1951, Бабић и др. }{ }^{2002} \text { [1996], Шипка } \\
\text { 2000, Анић и Силић 2001, Хрватски правопис 2013) }\end{array}$ \\
\hline$=$ & $\begin{array}{l}\text { знак једнакости (Белић 1950, Правопис 1960, Пешикан и } \\
\text { др. 1993, Бабић и др. }{ }^{6} 2002 \text { [1996], Шипка 2000, Пижурица } \\
\text { и др. 2010, Дешић 2015) }\end{array}$ \\
\hline
\end{tabular}

${ }^{6}$ Термин знак дужине ови аутори резервишу само за знак дужине који има угласти облик, али кажу и следеће: „Ненаглашени дуги вокал [...] у тексту се обележава на два начина: - у општем језику угластим знаком дужине (^) [...], - у стручном језику лингвистике равном хоризонталном цртом изнад самогласничког слова ( ) [...]” (стр. 140). Тако, заправо, није јасно терминолошко решење ни за један од ових знакова.

${ }^{7}$ По овим ауторима, коса црта може бити ,jединачна или удвојена” (Симић и др. 1998: 122). 


\begin{tabular}{|c|c|}
\hline$\circ$ & $\begin{array}{l}\text { знак степена (Пешикан и др. 1993, Шипка 2000, Пижурица } \\
\text { и др. 2010, Дешић 2015) }\end{array}$ \\
\hline$\%$ & $\begin{array}{l}\text { знак процента (Пешикан и др. 1993, Шипка 2000, Пижури- } \\
\text { ца и др. 2010) } \\
\text { знак за постотак (Хрватски правопис 2013) }\end{array}$ \\
\hline$\%$ & знак промила (Пешикан и др. 1993, Шипка 2000) \\
\hline & $\begin{array}{l}\text { низ тачака (Симић и др. 1998) } \\
\text { више тачака (Шипка 2000) }\end{array}$ \\
\hline ) & $\begin{array}{l}\text { полузаграда (Дешић 2015) } \\
\left.\text { лук (Бабић и др. }{ }^{6} 2002[1996]\right) \\
\text { десна заграда (Хрватски правопис 2013) }\end{array}$ \\
\hline - & $\begin{array}{l}\text { знак за растављање и означивање несамосталних облика } \\
\text { (Хрватски правопис 2013) }\end{array}$ \\
\hline [ситне бројке] & $\begin{array}{l}\text { ситне бројке (Пешикан и др. 1993, Пижурица и др. 2010, } \\
\text { Дешић 2015), } \\
\text { експонентне бројке (Шипка 2000) } \\
\text { експонирани број (Анић и Силић 2001), } \\
\text { повимена бројка (Бабић и др. }{ }^{6} 2002 \text { [1996]) }\end{array}$ \\
\hline$"$ & $\begin{array}{l}\text { двојни апостроф (,дето”) (Пешикан и др. 1993), } \\
\text { знак понављаъа (Бабић и др. '2002 [1996]), } \\
\text { знак понављаъа (,„дето”) (Пижурица и др. 2010) }\end{array}$ \\
\hline «"، & знак понављања или знак истости (Шипка 2000) $)^{10}$ \\
\hline$\sim$ & $\begin{array}{l}\text { тилда (Пешикан и др. 1993, Шипка 2000, Дешић 2015), } \\
\text { „тилда” (Пижурица и др. 2010) } \\
\text { вијугава цртица (Шипка 2000) }\end{array}$ \\
\hline$\approx$ & удвојена тилда (Пижурица и др. 2010) \\
\hline$\rightarrow$ & $\begin{array}{l}\text { стрелица (Пешикан и др. 1993, Шипка 2000), } \\
\text { знак упућиваға (Пижурица и др. 2010) }{ }^{11}\end{array}$ \\
\hline$>,<, \rightarrow$ & знакови за упућивање (Хрватски правопис 2013) \\
\hline.$\cdot$ & $\begin{array}{l}\text { „mрема” (Пешикан и др. 1993, Шипка 2000, Пижурица и } \\
\text { др. 2010) }\end{array}$ \\
\hline$\circ$ & $\begin{array}{l}\text { кружић испод слоготворног слога за обележавање суглас- } \\
\text { ника (Пижурица и др. 2010) }\end{array}$ \\
\hline
\end{tabular}

${ }^{8}$ Шипка (2000) не даје тачно графичко решење за знак који назива више тачака.

${ }^{9}$ Пешикан и др. (1993) прецизирају да се ситне бројке могу писати као експонентне (подигнуте) и индексне (спуштене), што преузимају и Пижурица и др. (2010) (Дешић 2015 помиње - свакако у складу са школском наменом свог правописа - само изразе подигнуте и спуштене); аутори који предлажу термине експонентне бројке и сличне термине ту разлику немају у виду.

${ }^{10}$ Као знак понављања или знак истости Шипка наводи два графичка решења: ” и -”-.

${ }^{11}$ Ови аутори знаком упућивања означавају и стрелицу у обрнутом смеру $(\leftarrow)$ (стр. 143). 


\begin{tabular}{|c|c|}
\hline $\mathrm{x}$ & $\begin{array}{l}\text { знак множења (Шипка 2000) } \\
\text { множни крижић (Бабић и др. }{ }^{6} 2002 \text { [1996]) }\end{array}$ \\
\hline- & $\begin{array}{l}\text { знак одузимаға (Шипка 2000) } \\
\text { знак мағе (минус) (Бабић и др. }{ }^{6} 2002 \text { [1996]) }\end{array}$ \\
\hline+ & $\begin{array}{l}\text { „плус” (Пешикан и др. 1993), } \\
\text { знак сабирања (Шипка 2000) } \\
\text { знак више (плус) (Бабић и др. }{ }^{6} 2002 \text { [1996]) }\end{array}$ \\
\hline$+-\mathrm{x} \cdot:$ & знакови математичких операчија (Хрватски правопис 2013) \\
\hline$=,>,<, \leq, \geq$ & знакови за односе (Хрватски правопис 2013) \\
\hline : & знак диобе (Бабић и др. ${ }^{6} 2002$ [1996]) \\
\hline : & знак за омјер (Хрватски правопис 2013) \\
\hline : & $\begin{array}{l}\text { знак за одјељивање сати и минута у временском запису } \\
\text { (Хрватски правопис 2013) }\end{array}$ \\
\hline / & разломачка ирта (Хрватски правопис 2013) \\
\hline // & двојна коса ирта (Пижурица и др. 2010) \\
\hline | & усправна ирта (Шипка 2000, Пижурица и др. 2010) \\
\hline$\|$ & двојна усправна ирта (Пижурица и др. 2010) \\
\hline$\dagger$ & $\begin{array}{l}\text { крижић (Бабић и др. }{ }^{6} 2002 \text { [1996]) } \\
\text { крстић (Шипка 2000) }\end{array}$ \\
\hline$\S$ & $\begin{array}{l}\text { параграф (Бабић и др. }{ }^{6} 2002 \text { [1996], Шипка 2000) } \\
\text { знак за чланак (Хрватски правопис 2013) }\end{array}$ \\
\hline [цифре ] & бројке (арапске и римске) (Боранић 1951) \\
\hline$\&$ & без термина (Дешић 2015) \\
\hline (a) & $\begin{array}{l}\text { без термина (Дешић 2015), знак којим се одјељује име при- } \\
\text { матеља електроничке поште и име послужиоиа (Хрватски } \\
\text { правопис 2013) }\end{array}$ \\
\hline
\end{tabular}

М. Дешић (2015) даје и табелу са „најчешћим изразима на интернету”: скраћенице $L O L, o m g$, четири емотикона, као и знакове за „like” i „share”.

5.2. Најпре неколико напомена у вези с појединачним знацима. У овом списку најчешћи знак је, свакако, цртица, будући да се налази на сваком месту где се реч дели на крају реда. Међутим, нереченични знак који први улази у правописе јесте апостроф: помиње га у групи интерпункцијских, као једини нереченични знак, још Љ. Стојановић (1892), с примерима из народне поезије: Скин' оружје, незнана делији, па нос' главу куда теби драго! и сл. Халидеј (1989: 33) у прегледу развоја правописних знакова помиње апостроф, уз цртицу и заграду, као знакове који су се јавили пре зареза, тачке и зареза, двотачке, црте, упитника и узвичника. Овде треба приметити да је у 
неким језицима - нпр. француском и енглеском - апостроф знатно важнији него у српском, јер су случајеви изостављања гласова одн. слова и систематски (везани за одређене облике лексема) и чести. Осим тога, у енглеском језику апостроф означава и посесивност, а у француском се обавезно јавља у одређеним случајевима кад глагол почиње самогласником. Стога се апостроф међу интерпункцијским знацима код Стојановића нашао можда и под страним утицајем.

Запажамо и да се знак ,)” у правописима разматра некад у оквиру заграде (тако чини Дешић 2015), а некад (такав је случај у два хрватска правописа) сматра посебним знаком (в. табелу).

Цифре правописним знацима сматра само Боранић (1951). То не изгледа оправдано, јер бисмо онда морали и слова сматрати правописним знацима.

5.3. Сад једно начелно разматрање. Примећује се да у новије време нереченични правописни знаци почињу да се „множе” у правописима - сваки нов правопис додаје још понеки такав знак. Стога се поставља питање критеријума за уношење помоћних правописних знакова у правопис.

Један критеријум помињу Пешикан и др. кад кажу (1993: 253):

Обрађиваће се они знакови и они поступци који спадају у општије правописне обичаје, који не остају ограничени на поједине струке и специјалности.

Подразумевани изузетак су специјализовани лингвистички знаци који се срећу у стручним лингвистичким текстовима одн. у речницима, као и општији знаци који у лингвистичкој струци имају специфичне употребе. Пешикан и др. (1993: 293-295) помињу следеће: знаке за акценте, знак краткоће и знак за ненаглашени дуги слог у облику равне црте, ${ }^{12}$ усправну ирту (која разграничава стихове), двојну усправну ирту (која се пише између алтернативних језичких облика и „означава цезуру у стиховима при њиховој анализи”), тилду (која се у речнику пише „уместо насловне речи, да се не би [та реч] посебно исписивала”, или означава „каткад и заменљивост, алтернацију две језичке јединице”), трему (као знак да се слово посебно чита, нпр. самогласничко $p$ ), стрелииу (којом се „у лексиконима и сл. каткад означава упућивање на другу заглавну реч”, или означава „развојни језички процес”). Такође помињу и специфично лингвистичке употребе звездице (да означи реконструисане или претпостављене речи и форманте, као и некњижевне речи) и косе црте (кад се пише „између напоредних или алтернативних језичких облика" или да разграничи стихове). Пижурица и др. (2010) додају знаке порекла (нпр. Žitbс̌а $>$ Жича, одн. Борча $<$ borbča $<$ Bогьсь $<$ Borislavъ), двојну косу ирту (која се може употребити уместо двојне усправне црте као знак за алтернативност), удвојену тилду (која означава „заманљивост (алтернацију) речи и израза") и кружић испод слоготворног сугласника. Може се поставити питање да ли је у правопису, који пре свега треба да се бави знацима опште

\footnotetext{
12 За „угласти знак дужине” кажу да га „пишемо у било ком тексту, али само по потреби - да се јасније разазнају речи" (1993: 293). - Да би се овај знак разликовао од знака дужине који употребљавају лингвисти у својим текстовима, било би добро увек га називати угластим.
} 
намене, место оволиком броју знакова који се јављају само у лингвистичким текстовима, одн. опширном опису таквих знакова.

Други критеријум за навођење помоћних правописних знакова се нигде у правописима не експлицира, али се подразумева (или би бар тако требало). Реч је о томе да је правопис (у смислу правила писања и књиге у којој су та правила дата) по дефиницији правопис природног језика, тј. да се у њему износе знакови и правила за записивање језика који се користи речима, а не знаци и правила за записивање неког специјализованог језика (какав се користи у математици, логици, хемији и др.), односно - ови други знаци се помињу само у оној мери у којој се срећу у неспецијализованим текстовима на природном језику, односно само у оним значењима које имају у општем језику.

Стога се традиционално у правописима од математичких знакова помиње само знак једнакости. Пешикан и др. (1993) додају и косу ирту у својству разломачке црте, знак степена, знак процента, знак промила, знак „, плус” - јер су, како кажу, „уобичајени”, одн. „добијају општију примену”. Дакле, још увек нема говора о увођењу математичких знакова у правописне приручнике (и у складу с тим се, рецимо, двотачка уопште не помиње у значењу које има у математици). Нешто другачије поступају Бабић и др. ('2002 [1996]: 124): они помињу све математичке знаке, с образложењем да ce „gdjekad upotrebljavaju i u običnome pisanju”, али инсистирају на њиховој нематематичкој употреби. Тако за знак минус кажу да служи најчешће „za označivanje temperaturnih stupnjeva ispod ništice”, множни крижић помињу пре свега као знак којим се означавају димензије: „npr. soba 5x4 m (soba duga pet, a široka četiri metra)" и сл. Ипак, помињу и употребу тачке као знака за „пута" у множењу и указују на то да се онда пише у средини ретка (исто: 451). Даље у томе иде Хрватски правопис 2013, који наводи не само математичке знакове за основне рачунске операције него и оне за односе $(=,>$, $<, \leq, \geq$ ). Иако то чини да би дао типографско упутство (,Ispred i iza znakova matematičkih operacija i odnosa nalaze se bjeline" (стр. 111)), на једном месту, говорећи о типовима заграда, напомиње да употреба неког типа заграда зависи од обичаја у одређеној струци, и као илустрацију дају једну математичку једнакост (стр. 103).

И у српској средини има аутора који сматрају да математичке знаке треба уврстити у правописне приручнике. Тако М. Шипка $(2000: 1416,1417)$ истиче потребу да се у наредна издања Правописа српскога језика (дакле после оног из 1993) унесу и термини (и „ноције”) знак сабирања, знак одузимања, знак множею $a .^{13}$ Слично предлаже и В. Брборић, коментаришући правопис Матице српске из 2010: „Чини се да би било боље да су уз основне и помоћ-

\footnotetext{
${ }^{13}$ Те појмове, мада не и одговарајуће термине, донекле уводи М. Дешић у свом школском правопису (Дешић 2015). На пример, иако знак једнакости дефинише само у вези с језиком, даје пример и из математике: „Знак једнакости (=) ставља се између речи и израза који означавају нешто што је једнако, а чита се као једнако је, исто ито, је: овог = овога, $3+3=6 "$ (стр. 193). И црту помиње као математички знак: „У математици се ставља црта између бројки, са значењем 'мање' или 'минус': $50-10=40$ ' (стр. 181). На сличан начин наводи се и математичка употреба двеју тачака (стр. 176). Међутим, нема математичке употребе заграде, а не говори се ни о знаку
} 
не интерпункцијске термине дати издвојени посебно математички знаци и њихови термини [...]” (Брборић 2018: 69), те као ,једну од могућих целовитости математичких знака” наводи: „знак сабирања, знак одузимања, знак дељења, знак множења, знак једнакости, знак неједнакости, знак приближности, мање од, више од, мање или једнако, више или једнако, знак степена, знак процента, знак промила, стрелицу на лево, стрелицу на десно, стрелицу лево-десно, стрелицу на горе, стрелицу на доле, стрелицу горе-доле” (исто: 69-70, у фусноти). И опет, у Закључку (стр. 71): „Сматрамо да математички и лингвистички термини спадају у интерпункцијске термине и да се у правопису мора наћи места и за њих."

Међутим, треба имати у виду две ствари. Прво је да правопис, како смо видели, треба да помене знакове који се срећу у текстовима на природном језику, и то у текстовима опште намене, и то најчешће такве знаке, ${ }^{14}$ и друго, имена и употребу математичких знакова прописује математика, а не лингвистика (као што и свака друга наука дефинише и именује знакове који спадају у њен метајезик). Стога бисмо рекли да систематском навођењу математичких симбола, као ни симбола било које друге науке, није у правопису место - исто онако као што није место ни свим могућим знацима који могу да се појаве у неком тексту.

\section{6. Како назвати неки правописни знак}

6.1. У малочас наведеној табели нереченичних знакова можемо запазити различите називе за знакове који имају исту форму; на пример, у Хрватском правопису 2013 знак који изгледа као две тачке једна изнад друге (и обично се назива две тачке или двотачка) има називе према својој употреби: двоточка (ако је интерпункцијски знак), знак за омјер и знак за одјељивање сати и минута у временском запису (ако је помоћни правописни). ${ }^{15}$ То отвара начелно питање - да ли је боље знак назвати према његовом изгледу (облику, форми), или према његовој употреби. То не важи само за помоћне правописне знакове: знак ,...” чак и у Правопису српскога језика Матице српске (и издању из 1993. и ономе из 2010) назива се знаком прекида - термином који је заснован на његовој употреби, а тек у загради стоји термин три тачке - који је заснован на његовој форми.

Таквих случајева је у прошлости било више. Тако се знак који се данас назива црта некад звао пауза (Стојановић 1891), станка (Боранић ${ }^{10} 1951$ [1921]), знак почивке (Новаковић 1894, Петровић 1912, Петровић 1914, Бе-

\footnotetext{
„,”. Јасно је да би доследно објашњење математичких симбола (поготово оних сложенијих) правописца одвело далеко.

${ }^{14}$ Треба се запитати и колико се често, и да ли се уопште у таквим текстовима срећу стрелице нагоре, надоле и горе-доле, знак неједнакости, знакови „мање од” и „више од” и сл.

${ }^{15}$ Такође, знак ,-" назива се и спојница и знак за растављање и означивање несамосталних облика; „, " и ,>> су и знакови за односе и знакови за упућивање; знак ,," је и коса ирта и разломачка ирта.
} 
лић 1923, Белић 1950), знак прекида (Новаковић 1894, Петровић 1912, Белић 1923) и прекидни знак (Белић 1934, Белић 1950, Ново правописно упутство [1943]) - што су све називи засновани на његовој употреби да означи паузу, да би се од Правописа 1960 усталио данашњи назив (први га употребљава Белић 1923), који одсликава његов изглед. Ако се, међутим, доследно примени принцип да се знак назива по његовој употреби, догодиће се да се исти назив употреби за два различита знака; на пример, С. Новаковић (1894) и М. Петровић (1912) знаком прекида називају и тротачку и црту. Стога је, начелно говорећи, боље знак назвати према форми, јер сваки има различите своје употребе, од којих се неке поклапају с употребама других знаковима.

Ако се неки знак употребљава у међусобно неповезаним значењима, и ако се увек означава истим именом, онда можемо рећи да је термин који га означава (нпр. две тачке или двотачка) хомонимичан. О тим и другим односима међу правописним знаковима биће више речи у т. 8 .

6.2. Неки правописни знаци имају, чак и ако је о једној средини реч, два назива. Тако Пижурица и др. (2010) дозвољавају, као што смо видели, два термина за знак ,...”: и знак прекида и три тачке. Осим - па чак и пре - термина две тачке Пешикан и др. (1993) наводе и термин двотачка. Исти аутори дозвољавају и више назива за знак ,,". У неформалној употреби двојстава има још више: осим најновијим правописом прописане запете, у широкој употреби је и зарез; осим упитника, узвичника и наводника у оптицају су и термини знак питања (свакако подржан и фразеологизмом бити под знаком питања), знак узвика и знак навода. И тако даље.

Иако већи број термина за један знак начелно није пожељан, приликом било каквих измена правописа - а то укључује и терминолошке измене мудро је следити савет П. Ивића (1998: 12-13):

Правопис има смисла мењати само ако је ново решење далеко боље од старог; иначе је грехота уносити забуну у публику, кршити створене навике, одучавати људе од наученог.

Дакле, ако је назив устаљен, не треба га мењати ако није изразито лош. Ако правописац мисли да постоји бољи, треба да га уведе, али да остави и први и да сачека да пракса каже своје. Избацивање устаљеног термина (као што је искључиво прописивање запете и тачке са запетом у правопису Пижурице и др. (2010)), сматрамо, није добро решење. ${ }^{16}$ Наиме, ако су термини прозирни, не би требало да представљају тешкоћу.

\footnotetext{
${ }^{16}$ Има и другачијих мишљења. Тако Брборић и Дешић (2003: 223) кажу: „Као што нису добра двострука правописна решења, једнако нису добри ни двоструки правописни термини. И једни и други слабе норму. [...] Двострука и трострука решења морају бити скраћена, јер је штета већа од добити коју они доносе.” - И Брборић (2018: 71) сматра да „дублетна решења нису најсрећнија, али [sic!] је вероватно најбоље да се полако њих ослобађамо”. Такође каже: „Није тешко утврдити који је термин бољи и коме ваља дати предност.” Проблем је, међутим, у томе што то често јесте тешко. Да ли је бољи термин запета, који је код Срба старији, или зарез, који се усталио и код Срба и још увек је уобичајен (в. о томе Кликовац 2018б)? С друге стране, термини двотачка и тротачка јасно су „бољи” од термина две тачке и три тачке, у том смислу што су једночлани и могу се употребити у контекстима у којима се ови потоњи не могу употребити (нпр. Избегавај много двотачки у тексту), али би инсистирање на њима као на јединима било насилно у односу на устаљену праксу.
} 


\section{7. Како се наглас читају правописни знаци}

7.1. Несумњиво је да „[в]елика већина писаних текстова, у наше време, нити настаје бележењем говора, нити је намењена читању наглас" (Клајн 2000: 139); стога и правописни знаци служе пре свега визуелној организацији текста. Ипак, они обично могу бити и прочитани наглас, и о томе ћемо рећи неку реч.

Приликом изражајног читања наглас интерпункцијски знаци се читају као паузе, при чему се оне комбинују и са другим елементима прозодије (нпр. испред зареза је тон типично подигнут, испред тачке, двотачке и тачке и зареза спуштен; део реченице између две ирте или унутар заграде може се читати бржим темпом и спуштеним тоном; реченица на чијем крају стоји упитник одн. узвичник изговара се са упитном одн. узвичном интонацијом и сл.). Изузетак су наводници, јер иако се део текста који се њима издваја може прочитати прозодијски другачије него остатак текста (нарочито кад је у питању управни говор у књижевним текстовима), они превасходно служе да том делу текста визуелно дају другачији статус у односу на остатак текста - статус цитата. ${ }^{17}$

7.2. Неки правописни знаци се читају наглас (и то може бити на различите начине), а неки се не читају. То одсликава њихову различиту природу и разнолике функције.

(1) Многи се читају као нека реч или израз. Такви су: знак процента, знак промила, знак степена, знаци порекла (и стрелица у истој употреби), знак једнакости, удвојена тилда („или”), коса ирта (у значењу разломачке црте „кроз”, између алтернативних облика „или”), двојна коса или усправна црта као знак алтернативних облика („или”), знак сабирања („плус”), ирта у значењу „минус", ${ }^{18}$ крстић (,умро”), знак „\&” („,”), стрелица одн. знак упућивања кад служи да се упути на другу одредницу у речнику („види”), две тачке („према”), ирта („од... до...”), заграда у случајевима као што је акцен(а)m (читају се оба облика, с речју „или” или „односно” између), тачка кад стоји између цифара које означавају сате и минуте (нпр. 5.30 се чита као „Пет сати и тридесет минута” или „пет и тридесет”) ${ }^{19}$.

Неки помоћни правописни знаци се читају тако што се изговара њихово име: зарез одн. запета (кад је у оквиру децималног броја: 2,5), па и ситне бројке кад значе „квадратни”, „кубни” и сл. (с тим што се онда читају као редни бројеви: „на трећи/четврти степен”). Неки се читају као нека већ употребљена реч или израз: тилда, знак понављањ а (овај други се може читати и као „исто”). Најзад, неки још немају устаљено име, па се читају на различите начине: знак „@, (који се најчешће чита, по енглеском узору, као „ет”, али у

\footnotetext{
${ }^{17}$ И неки други интерпункцијски знаци одређеном делу текста дају посебан статус: тачка, упитник, узвичник, а у неким употребама и тротачка одсечку текста дају статус реченице, а заграда - статус мање важног дела текста.

${ }^{18}$ На исти начин се читају и други математички знаци.

${ }^{19}$ Ова употреба тачке се, иначе, не може наћи у српским правописима, али је свакако важна.
} 
неформалном говору има и друге, сликовите називе - в. Новокмет 2014), а и знак „\&"20.

Знаци из ове групе очигледно чине текст краћим (слично скраћеницама) и додају му извесну иконичку димензију, захваљујући којој се он лакше прати и интерпретира. Неки од њих су неопходни, а неки уобичајени.

(2) Неки се не читају посебно, али се захваљујући њима реч изговара на одређени начин. Тако се понашају знакови за акценте, знак краткоће, угласти знак дужине, знак за ненаглашену дужину, „трема”, кружић испод слоготворног сугласника; у текстовима опште намене нарочито је важан угласти знак дужине, који може отклонити двосмисленост. Цртица чини да се реч изговара подељена на делове (кад се помоћу цртице дели на морфеме, слогове и сл.).

(3) Неки се не читају, и не могу се читати, јер им је функција управо да означе да су слово/слова или део текста изостављени: апостроф, низ/више тачака.

(4) Неки се не читају, али чине да неки део текста стекне одређени статус: различити знаци за раздвајање стихова (коса црта, усправна ирта, двојна усправна црта); знак за параграф. Сличну функцију, али помоћу својства да упућују на фусноту, имају звездица и експонентне ситне бројке.

(5) Има оних који се не читају посебно, али дају низу слова одн. цифара одређену интерпретацију: иртица кад се пише испред суфикса, иза префикса и сл.; тачка кад означава да је нешто скраћеница или да неки број треба читати као редни; различити знаци који означавају да је број редни (нарочито приликом набрајања ставки): заграда, полузаграда (други део заграде), евентуално знак степена - нпр. 1., 1), (1) или $1^{\circ}$. Слична је и тачка у вишецифреним бројевима, захваљујући којој се величина таквог броја лакше уочава.

\section{8. Односи међу правописним знацима}

Међу правописним знацима можемо запазити неке односе у које обично ступају лексеме и граматичке конструкције. Детаљно испитивање тих односа превазилази оквире овог рада, те ћемо их само забележити и илустровати понеким примером.

Најпре, два правописна знака (а понекад и више њих) могу имати у датом контексту исто или слично значење - што бисмо могли назвати правописном синонимијом. На пример, ради најаве објашњења или конкретизације

\footnotetext{
${ }^{20}$ Овај знак је графички настао као лигатура од латинског $E T$ и значио је „и”, а име које има у енглеском - ampersand - добио је сажимањем начина на који су га ђаци читали у алфабету - and per se and (подаци су добијени са следећих сајтова: https://en.oxforddictionaries.com/ explore/origin-of-ampersand/, https://www.merriam-webster.com/dictionary/ampersand, https://www. collinsdictionary.com/dictionary/english/ampersand (сајтови посећени 30. 8. 2018). Истог је порекла и његово име у француском - esperluette (постало од et per lui et) (https://fr.wikipedia.org/wiki/ Esperluette, сајт посећен 15. 7. 2019). У нашем језику би најприкладнији израз вероватно био комериијално ,, и” (што је решење којем прибегавају и неки други језици).
} 
неког појма могу се употребити и двотачка и црта (пр. 1) ${ }^{21}$; за обележавање уметнутог текста могу се, осим заграде, употребити и две црте или два зареза - при чему сваки знак има своју стилску вредност (пр. 2, где се може запазити силазна градација по важности уметнутог дела) ${ }^{22}$; термин се може означити наводницима или курзивом (пр. 3); управни говор се може означити и наводницима и цртом; да раздвоји ставке у набрајању, у неким случајевима може се употребити и зарез и тачка са зарезом; редни број се, приликом набрајања ставки, може означити различитим помоћним правописним знацима (в. малочас наведени пр. под (5) у т. 7.2) итд.

(1a) Наишле су разне недаће - женина болест, неродна година, одлазак сина у војску.

(1б) Наишле су разне недаће: женина болест, неродна година, одлазак сина у војску.

(2a) Цртом се - слично зарезу и загради - може издвајати уметнути део текста [...].

(2б) Цртом се, слично зарезу и загради, може издвајати уметнути део текста.

(2в) Цртом се (слично зарезу и загради) може издвајати уметнути део текста.

(3а) Термином интерпункција означаваћемо само реченичне знаке.

(3б) Термином „интерпункција” означаваћемо само реченичне знаке.

Затим, један правописни знак (пре свега интерпункцијски) може имати више повезаних значења одн. употреба - што бисмо могли назвати правописном полисемијом. Како се чини, та значења одн. употребе најчешће су конкретизације једног истог општег значења одн. употребе. Примера ради, двотачка означава паузу која служи најави, а та се најава може конкретизовати као најава управног говора, најава објашњења или конкретизације неког појма, најава узрока, последице, закључка или премисе, најава примера итд. (детаљно о употребама двотачке в. Кликовац 2014). Слично томе, „раздвојна" (како кажу Пешикан и др. (1993: 276)) функција црте такође се може конкретизовати на различите начине. Могуће је, међутим, да се, као у случају тротачке, образује читава значењска мрежа заснована на тзв. породичним сличностима (в. Кликовац 2012). У т. 4.3. видели смо да се неке употребе упитника и узвичника изводе од њихове основне употребе метонимијом. Више података о правописној полисемији, као и о структури категорија правописних знакова, може се добити, наравно, тек после детаљне анализе употребе свих правописних знакова.

А ако исти графички облик има значења одн. употребе који нису у међусобној вези, имамо посла с правописном хомонимијом. То је систематски случај са интерпункцијским знаковима који могу служити и као нереченични

\footnotetext{
${ }^{21}$ Реченицу (1а) наводе Пешикан и др. (1993: 275), с напоменом да црта ту ,алтернира са двема тачкама, а делимично и са зарезом".

${ }^{22}$ Реченицу (2а) употребљавају Пешикан и др. (1993: 275), и користе као илустрацију правила које се њоме износи.
} 
знаци: тачка кад означава крај реченице на једној страни и тачка иза редног броја или иза скраћеница на другој; двотачка у интерпункцијској употреби и двотачка у значењу „према”; црта као интерпункцијски знак и у значењу „од... до...” итд. Односи хомонимије важе и између помоћних правописних знакова. На пример, хомонимичне су коса црта која стоји између алтернативних облика и разломачка коса црта; тачка иза скраћеница и тачка која означава да је број редни итд.

\section{9. Дефиниција правописних знакова уопште}

У правописима не наилазимо често на дефиниције свих правописних знакова заједно. Симић и др. (1993: 129) у једној реченици употребљавају израз „знаци придодати словима”. Анић и Силић (2001: 9) дају дефиницију која је и неодређена и нејасна: „Pravopisni su znakovi pismeni znakovi kojima se obilježavaju pravopisni odnosi u tekstu." Наиме, није очигледно шта би то били ,правописни односи у тексту”.

Дешић (2015) каже: „Правописни знаци су знаци који се употребљавају, према одређеним правилима, да би се боље разумео садржај писаног текста, да би читаоци боље схватили поруке које су им упућене” (стр. 161, курзив изворни). Ова дефиниција садржи најважније својство правописних знакова - а то је да помажу разумевање писаног текста, а довољно је широка (,употребљавају се”) да обухвати и знаке који се не пишу а функционишу као правописни (од таквих знакова Дешић помиње типове слова).

Брборић (2018: 68) каже да су то „они [знаци] који се употребљавају у писању ради јаснијег обележавања онога што се пише, па можемо рећи да су то сви знаци који нису слова, а пишемо их у неком тексту". Ова дефиниција обухвата типичне случајеве правописних знакова, али је у односу на све правописне знакове и преширока и преуска. Преширока - зато што би обухватала и цифре као правописне знакове, а преуска - зато што обухвата само оне правописне знаке који се пишу. Наиме, неки од њих се не пишу као посебни (као што су управо поменути типови слова, или велико слово на почетку реченице) или се уопште не пишу (видели смо да неки аутори у правописне знакове укључују и белине, поделу текста на пасусе итд.). Такође, и правописни знаци у ужем смислу (а то су они који се заиста дописују тексту) пишу се не само уз слова него и уз цифре (нпр. зарез у децималним бројевима, тачка у вишецифреним бројевима итд.).

Ако бисмо све то имали у виду, правописне знакове бисмо могли дефинисати као знакове који се комбинују са словима или, евентуално, цифрама да би се добио јасан, прегледан писани текст. Они олакшавају читање и разумевање текста тако што га рашчлањују, прецизирају и чине прегледнијим. 


\section{0. Закључак}

Што се тиче термина помоћни правописни знащи, његови творци - Пешикан и др. 1993 - приписали су му значење нереченичних знакова. Сматрамо да тако треба и да остане, тј. да је разлика између реченичних и нереченичних знакова суштинска и начелна и да се не сме изгубити из вида.

Помоћне правописне знаке је практично немогуће обухватити једном дефиницијом; за њих се једино може рећи да служе за „различите посебне потребе" (Пешикан и др. 1993), одн. могу се обухватити негативним својством да нису интерпункцијски.

Интерпункцијски знаци који се употребљавају и као помоћни правописни јесу тачка, зарез, двотачка, ирта, заграда и тротачка. Интерпункцијски знаци који се употребљавају на нивоу текста - а то су црта, тротачка, заграда и наводници - задржавају и тада своје интерпункцијско значење. Такође, интерпункцијски знак не губи нужно ту своју природу и ако се веже само за једну реч (упитник, узвичник, наводници).

Што се тиче критеријума по којима се помоћни правописни знаци уносе у правописе, сматрамо да треба водити рачуна о томе да правопис прописује правила записивања природног језика, а помиње оне знакове који се налазе у таквим текстовима опште намене, и то најчешће такве знакове (уз изузетак најчешћих лингвистичких знакова); стога у њему није место оним знацима чије значење и употребу прописују друге науке (математика, физика, хемија итд.).

Правописни знак се може назвати према својој употреби и према свом облику (графичком решењу). Ово друго се чини практичнијим, јер се тиме избегава да се знаци који изгледају различито назову истим именом. С друге стране, иако је, начелно говорећи, пожељно да сваки знак има по једно име, сматрамо да на томе не треба инсистирати по сваку цену, укидајући устаљене обичаје.

Правописни знаци се обично могу прочитати наглас. Приликом изражајног читања интерпункцијски знаци се читају као паузе, обично у комбинацији с другим елементима прозодије. Помоћни правописни знаци се читају на више начина - или се уопште не читају; то одсликава њихову различиту природу и разнолике функције.

Интерпункцијски знаци, иако су настали људском интервенцијом, у једном погледу се понашају слично лексемама и граматичким конструкцијама: полисемични су, тј. њихова значења и употребе сачињавају категорију; некада постоји неопходан и довољан услов за чланство у њој - тј. једно опште значење које обухвата сва значења, али некада се формирају и другачије категорије. Ако нека значења одн. употребе припадају двема, па и трима категоријама правописних знакова, имамо посла с правописном синонимијом. 
А у случајевима кад један исти графички облик има међусобно неповезане употребе, можемо говорити о правописној хомонимији.

Правописне знакове уопште можемо дефинисати као знакове који се комбинују са словима или, евентуално, цифрама да би се добио јасан, прегледан писани текст. Они се могу тексту дописивати, али могу се и на друге начине с њим комбиновати.

\section{ЛИТЕРАТУРА}

Анић/Силић 2001: Vladimir Anić, Josip Silić, Pravopis hrvatskoga jezika, Zagreb: Novi Liber.

Бабић и др. ${ }^{6} 2002$ [1996]: Stjepan Babić, Božidar Finka, Milan Moguš, Hrvatski pravopis, Zagreb: Školska knjiga.

Белић 1923: Александар Белић, Правопис српскохрватског књижевног јези$\kappa a$, Београд: Издавачка књижарница Геце Кона.

Белић 1934: Александар Белић, Правопис српскохрватског књижевног језика (Према прописима Министарства просвете), (треће, поправљено издање), Београд: Издавачко и књижарско предузеће Геца Кон.

Белић 1950: Александар Белић, Правопис српскохрватског књижевног јези$\kappa a$ (ново, допуњено и исправљено издање), Београд: Просвета.

Боранић ${ }^{10} 1951$ [1921]: D. Boranić, Pravopis hrvatskoga ili srpskoga jezika, Zagreb: ک̌kolska knjiga.

Брборић 2018: Вељко Брборић, „Интерпункцијска терминологија код Срба од Вука до данас", у: Српска славистика - Колективна монографија, Том I: Језик, Београд: Савез славистичких друштава Србије, 61-73.

Брборић/Дешић 2003: Вељко Брборић, Милорад Дешић, „О стандардизацији правописне терминологије", Научни састанак слависта у Вукове дане, 42/3, 219-227.

Броз 1892: Ivan Broz, Hrvatski pravopis, Zagreb.

Дешић 1994: Милорад Дешић, Правопис српског језика - Приручник за школе, Земун: Нијанса / Никшић: Унирекс.

Дешић 2015: Милорад Дешић, Правопис српског језика - школско издање, Београд: Klett.

Ивић 1998: Павле Ивић, „Из прошлости српског правописа”, у: $K$ новој писмености (приредио Р. Гачевић), Београд: Научна књига, 11-15.

Клајн 2000: Иван Клајн, „Конвенционално и суштинско у правопису”, у: Лингвистичке студије, Београд: Партенон.

Кликовац 2011а: Душка Кликовац, „О обради запете у новом издању Правописа српскога језика (Матица српска, 2010)", Кюижевност и језик, LVIII: 1-2, 115-124.

Кликовац 2011б: Душка Кликовац, „О обради интерпункције у старом и новом издању Правописа српскога језика (Матица српска, 2010)”, Къижевност и језик, LVIII: 3-4, 229-248. 
Кликовац 2012: Душка Кликовац, „О интерпункцијском знаку три тачке (тротачки)", Научни састанак слависта у Вукове дане, 41/3, 63-92.

Кликовац 2014: Душка Кликовац, „О двотачки”, Научни састанак слависта у Вукове дане, 43/3, 113-153.

Кликовац 2017: Душка Кликовац, „О знаковима у правопису (1): подела на реченичне и нереченичне и одговарајућа терминологија”, Научни састанак слависта у Вукове дане, 46/3, 2017, 95-111.

Кликовац 2018a: Душка Кликовац, „О знаковима у правопису (2): реченични знакови", Научни састанак слависта у Вукове дане, 47/3, 69-85.

Кликовац 2018б: Душка Кликовац, „О зарезу иза односних реченица са ко, што (и коментар о термину за означавање тог интерпункцијског знака)", Језик данас, XIV, 12, 26-31.

Новаковић 1894: Стојан Новаковић, Српска граматика, Београд: Државна штампарија.

Новокмет 2014: Слободан Новокмет, „Како зовемо симбол @?”, Језик данас, $\mathrm{X}, 1-2,42-46$.

Ново правописно упутство [1943]: Ново правописно упутство српског књижевног језика, Београд: Министарство просвете.

Петровић 1912: Милан Петровић, Српска граматика с правописом, Нови Сад.

Петровић 1914: Милан Петровић, Српски правопис за средње школе, Нови Сад.

Пешикан и др. 1993: Митар Пешикан, Јован Јерковић, Мато Пижурица, Правопис српскога језика, Нови Сад: Матица српска.

Пижурица и др. 2010: Митар Пешикан, Јован Јерковић, Мато Пижурица, Правопис српскога језика, измењено и допуњено издање (Редакција: Мато Пижурица (главни редактор), Милорад Дешић, Бранислав Ocтојић, Живојин Станојчић), Нови Сад: Матица српска.

Правопис 1960: Правопис српскохрватскога књижевног језика, Нови Сад - Загреб: Матица српска - Матица хрватска.

Правописно упутство [1929]: Правописно упутство за све основне, средюе и стручне школе, Београд: Државна штампарија Краљевине Југославије.

Симић и др. 1993: Радоје Симић, Живојин Станојчић, Бранислав Остојић, Божо Ћорић, Милош Ковачевић, Правопис српскога језика са рјечником, Никшић: Унирекс, 1993.

Симић и др. 1998: Правописни приручник српскога књижевног језика (приредила правописна комисија, одг. ред. Радоје Симић), Београд: Научно друштво за неговање и проучавање српског језика.

Стојановић 1891: Љубомир Стојановић, Лекције из српскога језика за II разред гимназије.

Халидеј 1989: М. А. K. Halliday, Spoken and Written Language, Oxford: Oxford University Press, 1989.

Хрватски правопис 2013: Hrvatski pravopis (gl. ur. Željko Jozić), Zagreb: Institut za hrvatski jezik i jezikoslovlje.

Шипка 2000: Милан Шипка, „О српској правописној терминологији”, Јужнословенски филолог, LVI/3-4, 1411-1417. 
Duška B. Klikovac

\section{ON MARKS IN ORTHOGRAPHY (3): NON-SENTENTIAL (SUBSIDIARY) MARKS AND SOME REMARKS ON ORTHOGRAPHIC MARKS IN GENERAL}

\section{Summary}

This paper (in continuation to Klikovac 2017 and 2018a) is structured in two parts. The first part deals with subsidiary (non-sentential, i.e. non-punctuation) orthographic marks, whereby the author comments on one emergent use of the term 'subsidiary orthographic marks' in the pertinent literature, provides an overview of the definitions of subsidiary orthographic marks given in the extant orthography manuals, considers the inventory of punctuation marks which can be used as subsidiary orthographic marks (and establishes that these include the full stop/period, comma, dash, colon, ellipsis/ three dots, and brackets/parentheses), provides an overview of the subsidiary orthographic marks listed in the extant orthography manuals, and argues against including mathematical symbols in orthography. In the second part, which deals with various aspects of orthographic marks in general, the author argues in favour of naming the orthographic mark according to its form (i.e. the graphic solution) rather than according to its function, considers the ways in which orthographic marks (including both punctuation and subsidiary marks) are read aloud, and establishes that the phenomena of polysemy, synonymy and homonymy, which are commonly associated with lexemes and grammatical constructions, are also observable in orthographic marks. In conclusion, all orthographic marks taken together are defined as signs which are combined with letters or, potentially, numbers, in order to achieve a clear, discernible written text; as such, they can be inserted into a text as additional written signs, but are also textually combinable in other ways. 